Research Paper

\title{
Endothelial nitric oxide synthase expression is progressively increased in primary cerebral microvascular endothelial cells during hyperbaric oxygen exposure
}

Xiongfei Xu, ${ }^{1, \dagger}$ Zhongzhuang Wang, ${ }^{2, \dagger}$ Quan Li, ${ }^{1,3}$ Xiang Xiao, ${ }^{1}$ Qinglin Lian, ${ }^{1}$ Weigang Xu, ${ }^{1}$ Xuejun Sun, ${ }^{1}$ Hengyi Tao ${ }^{1}$ and Runping $\mathrm{Li}^{1}{ }^{1, *}$

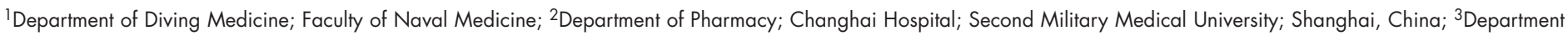
of Biochemistry; School of Medicine; Qingdao University; Qingdao, Shandong China

tThese authors contributed equally to this work.

Key words: cerebral microvessel, endothelial cells, hyperbaric oxygen, nitric oxide synthase

Exposure to hyperbaric oxygen ( $\mathrm{HBO}$ ) can lead to seizures. Many studies have demonstrated that there exist a very close relationship between the alteration of cerebral blood flow (CBF) and the onset of seizures. Nitric oxide (NO) may play a key role in the change of $\mathrm{CBF}$ during exposure, and modulation of endothelial nitric oxide synthase (eNOS)-derived $\mathrm{NO}$ by $\mathrm{HBO}$ is responsible for early vasoconstriction, whereas late $\mathrm{HBO}$-induced vasodilation depends upon a large amount of NO from both eNOS and neuronal nitric oxide synthase (nNOS). To investigate the effect of $\mathrm{HBO}$ on the activity and expression of eNOS in cerebral microvascular endothelial cells (CMEC) in vitro, primarily cultured CMEC from neonatal rats were exposed to oxygen at $500 \mathrm{kPa}$ [5 atmosphere absolute (ATA)] for 10, 20, 30, 60 and 120 minutes (min), then eNOS activity, protein and mRNA contents in cells were detected. Our results showed that immediately after exposure, 30, 60 and 120 min HBO exposures did not alter NOS activity. When detected no matter immediately or six hours (h) after exposure, these exposures also did not alter eNOS protein and mRNA levels. However, when detected $24 \mathrm{~h}$ after exposure, 30, 60 and $120 \mathrm{~min}$ exposures upregulated eNOS protein content by $39 \%$, $60 \%$ and $40 \%$ respectively. 10 and 20 min exposures upregulated eNOS mRNA content by about $15 \%$, while 30,60 and $120 \mathrm{~min}$ exposures upregulated it by about $20-30 \%$. The increased eNOS protein and mRNA contents at $24 \mathrm{~h}$ after exposure may reflect new protein synthesis for eNOS. Our studies showed that with the exposing protocols we used, $\mathrm{HBO}$ did induce eNOS expression increase in CMEC. However, compared with the decrease of $\mathrm{CBF}$ in vivo, which occurred in a relative short time after rat was exposed to $\mathrm{HBO}$ above $4 \mathrm{ATA}$, the responses of eNOS in CMEC in

\footnotetext{
*Correspondence to: Runping Li; Department of Diving Medicine; Faculty of Naval Medicine; Second Military Medical University; 800, Xiangyin Road; Shanghai 200433 China; Tel.: +86.21.25074454; Fax: +86.21.65492382; Email: smartrpli@hotmail.com
}

Submitted: 11/12/08; Revised: 12/20/08; Accepted: 12/22/08

Previously published online as an Oxidative Medicine and Cellular Longevity

E-publication: http://www.landesbioscience.com/journals/oximed/article/7697 vitro were a little slow. Thus we considered that for the vasodilation in the late period of $\mathrm{HBO}$ exposure before seizure, the effect of NO produced by eNOS was limited.

\section{Introduction}

Prolonged exposure to hyperbaric oxygen (HBO) is essential in some clinical and operational situations and can result in central nervous system (CNS) and pulmonary oxygen toxicity. The neurological manifestations of $\mathrm{HBO}$ toxicity include a variety of signs and symptoms ranging from anxiety, nausea, altered vision and hearing to muscular twitching, unconsciousness and convulsions. It has been reported that during $\mathrm{HBO}$ exposure, cerebral blood flow (CBF) decreased initially, then increased well before seizure onset. ${ }^{1-4}$ Therefore CBF increase could act as an objective pre-convulsive index and the overproduction of nitric oxide played an important role in such increase. The studies by Atochin et al. using endothelial nitric oxide synthase $(\mathrm{eNOS})^{-/-}$and neuronal nitric oxide synthase $(\mathrm{nNOS})^{-/-}$mutant mice suggested that eNOS derived nitric oxide (NO) was responsible for the early vasoconstriction responses, whereas late $\mathrm{HBO}$-induced vasodilation depended upon both eNOS and nNOS. ${ }^{5}$ On the other hand, Hagioka et al. used selective nNOS inhibitor (7-NI) and the nonselective NOS inhibitor (L-NAME) elucidated the origins of $\mathrm{NO}$ production. Their data suggested that nNOS was the main mediator of NO production associated with increase in $\mathrm{CBF}$ during $\mathrm{HBO}$ exposure. ${ }^{6}$ To examine the exact inducible factor of HBO-induced vasodilation will be helpful to elucidate the mechanism of oxygen convulsion and to provide novel thoughts against this illness.

In this study, we investigated the direct effects of $\mathrm{HBO}$ exposure on primarily cultured rat cerebral microvascular endothelial cells (CMEC). After CMEC were exposed to 5 atmosphere absolute (ATA) $100 \% \mathrm{O}_{2}$ for diverse exposure and sequentially cultured periods, eNOS activity, protein and mRNA levels in CMEC were detected. 


\section{Results}

Effect of $\mathrm{HBO}$ exposure on the morphology of cultured endothelial cells. With an $\mathrm{HBO}$ exposure period of 120 minutes ( $\mathrm{min})$, the morphology of CMEC had no notable changes, no matter observed immediately after exposure or after the cells was sequentially cultured in $95 \%$ air- $5 \% \mathrm{CO}_{2}$ surroundings for 24 hours (h). The cells kept fusiform shape as that before exposure. Neighboring cells tightly attached to each other. Cells adhered to the culture dishes tightly. No notable decrease of cell quantity was observed (Fig. 1).

Effect of $\mathrm{HBO}$ exposure on viability of cultured endothelial cells. When detected $24 \mathrm{~h}$ after exposure, we found the viabilities of $\mathrm{CMEC}$ exposed to $\mathrm{HBO}$ and hyperbaric air (HBA) for 60 min were significantly higher than that of CMEC exposed to HBO for 120 min and normobaric air (NBA) ( $\mathrm{p}$ $0.01)$. There was no significant difference between the viabilities of CMEC exposed to $\mathrm{HBO}$ and that of CMEC exposed to HBA for $60 \mathrm{~min}$. Also no significant difference existed between the viabilities of CMEC exposed to $\mathrm{HBO}$ for $120 \mathrm{~min}$ and that of CMEC exposed to NBA ( $p>0.05$ ) (Fig. 2).

Effect of $\mathrm{HBO}$ exposure on NOS activity in cultured endothelial cells. Nitric oxide synthase (NOS) activity in CMEC was measured immediately after exposure. Compared with NOS activity in CMEC exposed to NBA, activity in CMEC exposed to HBA for $60 \mathrm{~min}$ was not changed significantly. Similarly, activities in CMEC exposed to $\mathrm{HBO}$ for 30, 60 and 120 min were kept unchanged (Fig. 3).

Effect of $\mathrm{HBO}$ exposure on eNOS protein level in cultured endothelial cells. Light microscopic immunocytochemistry showed that eNOS was expressed in confluent endothelial cells in culture. eNOS was localized mainly in a paranuclear position, especially on one side of the nucleus (Fig. 4A and B). When compared no matter immediately or $6 \mathrm{~h}$ after exposure, there were no significant differences among the color intensities of stained eNOS protein in CMEC exposed to NBA, HBA and HBO for 60 and 120 min (Fig. 4A and B).

Western blotting analysis also indicated that eNOS protein contents in CMEC exposed to HBO for 60 and 120 min were not different from those in CMEC exposed to NBA or to HBA for 60 min, when detected no matter immediately or $6 \mathrm{~h}$ after exposure $(\mathrm{p}>0.05)$ (Fig. 5A and B).
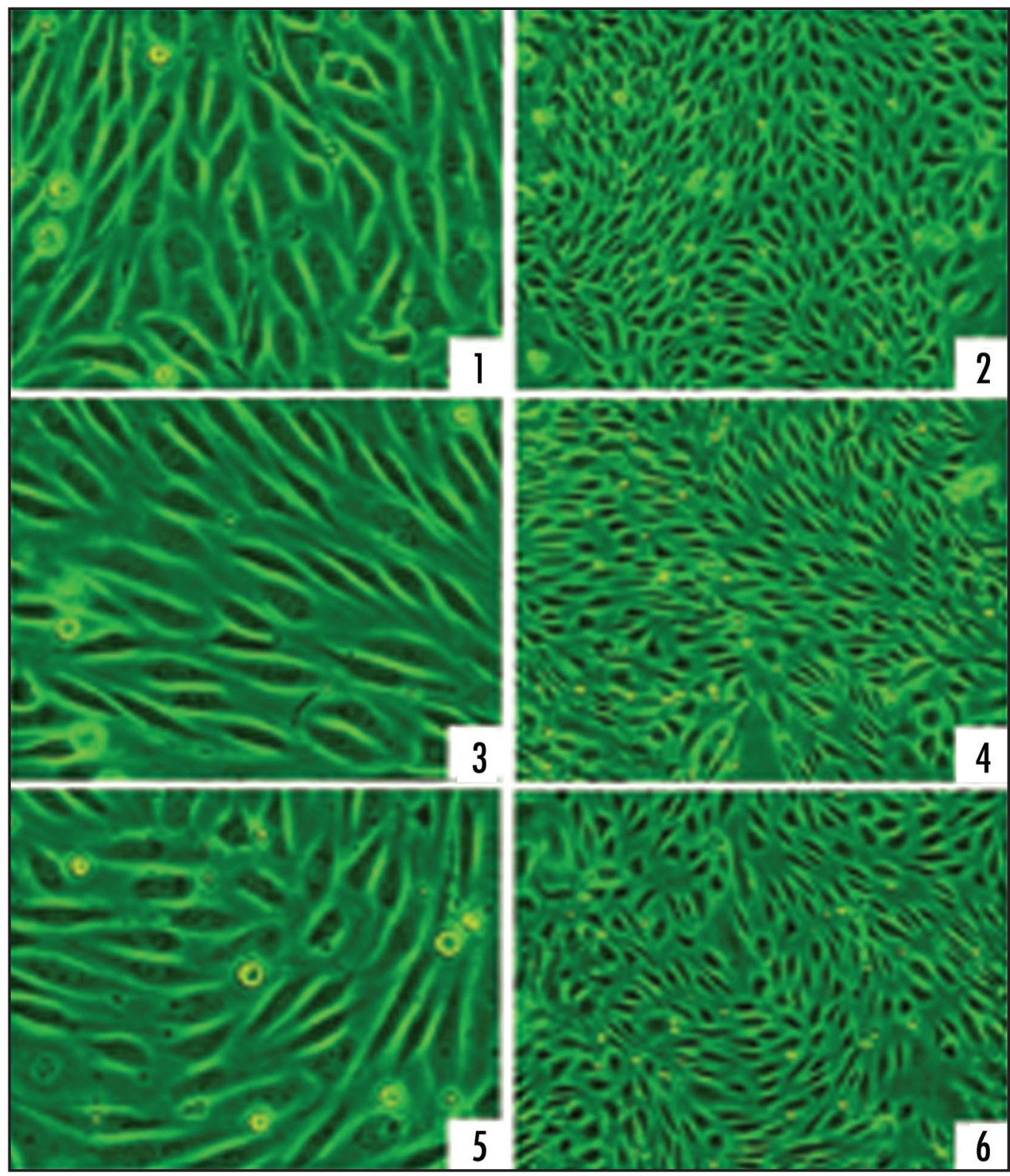

Figure 1. Light microscopy representative images of CMEC morphology before and after $\mathrm{HBO}$ exposure. (1 and 2): CMEC of pre-exposure; (3 and 4): CMEC at the moment immediately after $120 \mathrm{~min} 500 \mathrm{kPa} \mathrm{HBO}$ exposure; (5 and 6): CMEC sequentially cultured in regular surroundings $\left(95 \%\right.$ air $\left.-5 \% \mathrm{CO}_{2}\right)$ for $24 \mathrm{~h}$ after exposed to $500 \mathrm{kPa} \mathrm{HBO}$ for $120 \mathrm{~min}, \mathrm{x} 100$ and $\times 40$ respectively.

When measured $24 \mathrm{~h}$ after exposure, compared with eNOS protein contents in CMEC exposed to NBA, those in CMEC exposed to $\mathrm{HBO}$ for 10 and 20 min kept unchangeable ( $\mathrm{p}>0.05$ ). However, as the exposure period prolonged, the eNOS protein contents increased. Figure 5C and D show 30, 60 and 120 min $\mathrm{HBO}$ exposure could increase eNOS contents by $39 \%, 60 \%$ and $40 \%$ respectively $(\mathrm{p}<0.01)$ (Fig. 5C and D).

Effect of HBO exposure on eNOS mRNA level in cultured endothelial cells. When detected no matter immediately or six hours after exposure, RT-PCR analysis showed that eNOS mRNA contents in $\mathrm{CMEC}$ exposed to $\mathrm{HBO}$ for 60 and $120 \mathrm{~min}$ were not different from those in CMEC exposed to NBA or to HBA for $60 \mathrm{~min}$ $(\mathrm{p}>0.05)$ (Fig. 6A and B).

However, when measured $24 \mathrm{~h}$ after exposure, compared with eNOS mRNA contents in CMEC exposed to NBA, 10 and $20 \mathrm{~min}$ 


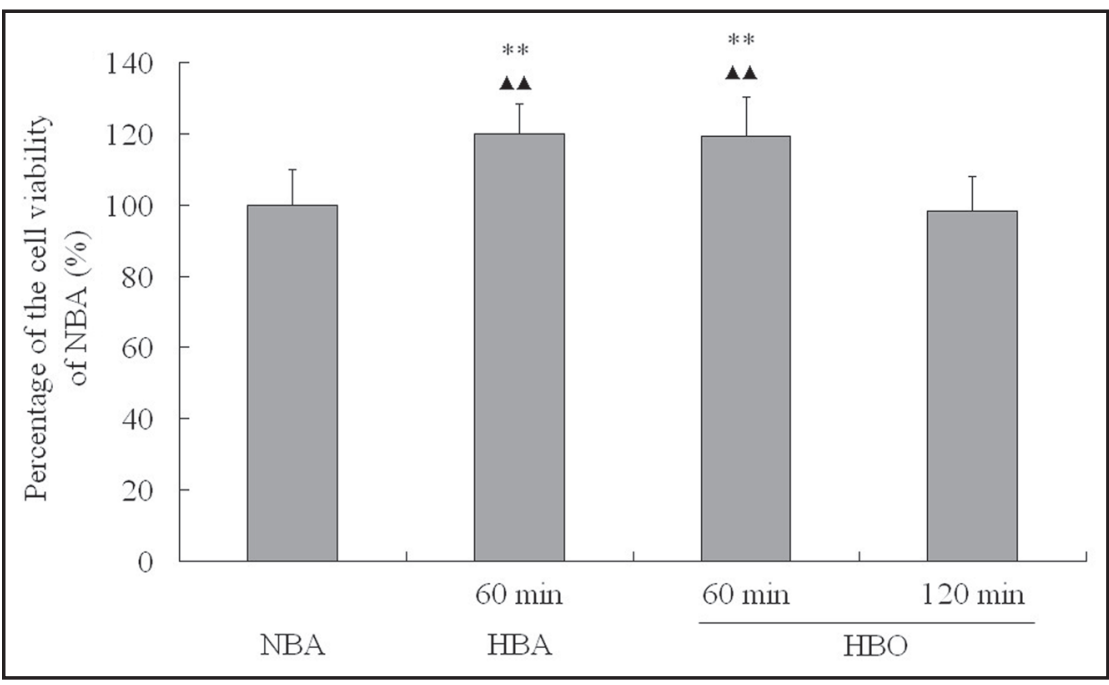

Figure 2. Cell viability of CMEC $24 \mathrm{~h}$ after different gas and period exposure. Cell viability was comparatively expressed as the percentage of the viability of cells cultured in regular surroundings (NBA, 95\% air-5\% $\mathrm{CO}_{2}$ ). ${ }^{* *} \mathrm{p}<0.01$ vs. $\mathrm{NBA} ;{ }^{\star \Delta} \mathrm{p}<0.01$ vs. $120 \mathrm{~min}$ $\mathrm{HBO}, \mathrm{n}=8$.

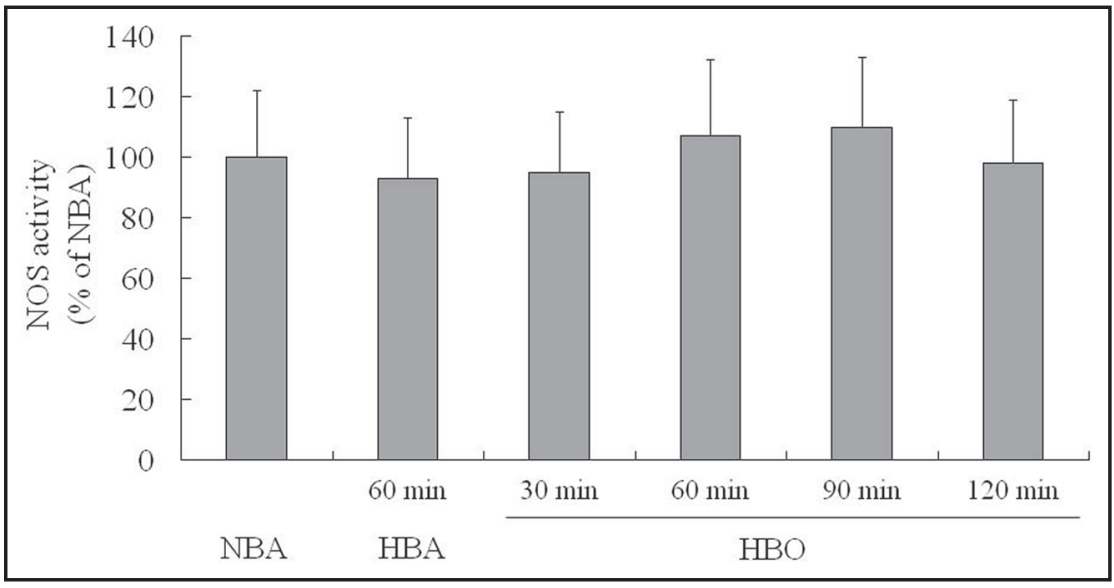

Figure 3. NOS catalytic activity in primarily cultured CMEC after different gas and period exposure. HBO exposure did not impact NOS activity in endothelial cells when detected immediately after exposure with an enough long $\mathrm{HBO}$ exposure period of $120 \mathrm{~min}$. NOS activity was presented as a percentage of NBA. $n=8$.

HBO exposure could increase eNOS mRNA level by about $15 \%$ $(\mathrm{p}<0.01)$, and 30,60 and $120 \mathrm{~min}$ exposure could increase it by about $20-30 \%(\mathrm{p}<0.01)$ (Fig. 6C and D).

\section{Discussion}

Effects of HBO exposure on the viability of in vitro cultured cells depend on many factors, such as the exposure pressure and period, the type, generation and age of cells, and so on. As for the $\mathrm{HBO}$ effects on the viability of endothelial cells, the results are different, promotion and inhibition were all possible. ${ }^{7-11}$ The effects of $\mathrm{HBO}$ exposure on the viability of in vitro cultured CMEC were not reported previously. According to the report of Buras, ${ }^{12}$ in our experiment, except for the temperature, humidity, $\mathrm{pH}$ value and $\mathrm{CO}_{2}$ concentration during exposure, we also limited the quantity of culture medium ( $1 \mathrm{ml}$ for $35 \mathrm{~mm}$ culture dish). In such condition, it could be ensured that the nutritive substances in medium were enough for cell survival. Meanwhile, oxygen partial pressure in medium could reach to the predetermined level within a quite short time (5 ATA within $20 \mathrm{~min}$ ), and this would be very favorable for investigations of HBO effects on cultured cells.

Based on the exposure methods, we found 120 min exposure to 5 ATA HBO produced no marked influences on the morphology and the quantity of CMEC when observed immediately after exposure. Even when observed at $24 \mathrm{~h}$ after exposure, the status remained unchangeable. The results of cell viability showed that there were no notable differences among the influences on cell viability of diverse exposure, although $60 \mathrm{~min}$ exposure could slightly increase cell viability. Meanwhile, we found such slight increase mainly resulted from the effect of high pressure, but not merely from $\mathrm{HBO}$, as there was no significant difference between the result of $60 \mathrm{~min} \mathrm{HBO}$ and 60 min HBA exposure. Summarily, we considered the exposure protocols we used had no notable influences on the living status of CMEC in certain period. On the base of such results, within certain period, the effects of $\mathrm{HBO}$ on the activity or content of a given enzyme or protein in CMEC would be direct and specific, and the potential changes of activity or content by $\mathrm{HBO}$ exposure would not be interfered by the living status of cells.

eNOS expression has been demonstrated in various types of endothelial cells, including CMEC. NO produced by CMEC may play a key role in the regulation of focal CBF under basal conditions. ${ }^{13}$ Studies in vivo had shown hyperoxia or hyperbaric oxygen exposure could change NO level in rat brain through modulating the activity and expression of eNOS and nNOS. But it was different on the point that which isoform of NOS is the main mediator. Thom et al. reported 2.8 ATA HBO exposure could increase NO concentration in rat cerebral cortex. ${ }^{4}$ Cerebral cortex blood flow increased during exposure and may be causally related to elevations of steady state NO concentration. Data showed nNOS activity contributes over $90 \%$ to total NO elevation. One important mechanism for nNOS activation was that $\mathrm{HBO}$ could trigger an increased association between nNOS and heat-shock protein (Hsp) 90, and subsequently increases intracellular $\mathrm{Ca}^{2+}$. Elayan et al. also reported a six- and fourfold increase in NO levels in the hippocampus and the striatum, respectively, of rats treated with $100 \% \mathrm{O}_{2}$ at 3 ATA for two hours. ${ }^{14}$ Through determining neuronal $\mathrm{NOS}_{2} \mathrm{Km}$, and using this value to estimate the effect of increasing brain $\mathrm{O}_{2}$ levels on $\mathrm{NO}$ production by nNOS, they found NO production by NOS closely matching the measured increase in vivo, indicating nNOS was mainly responsible for cerebral $\mathrm{NO}$ elevation under $\mathrm{HBO}$ conditions.

Studies on the relations among NO, oxygen free radicals and CBF revealed that $\mathrm{HBO}$ could cause a decrease in $\mathrm{CBF}$ in short period exposure. Such decrease was resulted from enhancing endogenous - $\mathrm{O}_{2}{ }^{-}$generation by hyperoxia, and because $\bullet \mathrm{O}_{2}{ }^{-}$was a rapid neutralizer of $\mathrm{NO}, \mathrm{NO}$ and its basal vasodilator effects were decreased. 
As a proof, superoxide dismutase (SOD) could suppress $\cdot \mathrm{O}_{2}^{-}$and increase $\mathrm{CBF}$. Further investigations using genetically altered rodents showed NO neutralized by $\cdot \mathrm{O}_{2}{ }^{-}$and responsible for cerebral vasoconstriction during breathing hyperbaric oxygen mainly consisted of eNOS-dependent NO. ${ }^{5,15-19}$ It was reasonable as the vascular endothelial cell and eNOS in it were the primary targets acted on by hyperoxia when high pressure oxygen was transported to brain.

As the exposure prolonged, although large numbers of oxygen free radicals were generated unceasingly, production of $\mathrm{NO}$ seemed to be more rapid due to the participation of abundant nNOS activated by $\mathrm{HBO}$, exhibiting as a marked rise of $\mathrm{CBF}$ in the later period of a continuous HBO exposure, which always predicated a subsequent $\mathrm{O}_{2}$ seizures. However, it was different on the point that which NOS isoform played a more important role in the modulation of the later vasodilation. Some considered NO by eNOS was responsible for the development of hyperoxic hyperemia preceding $\mathrm{O}_{2}$ seizures, whereas neuronal $\mathrm{NO}$ may mediate toxic effects of $\mathrm{HBO}$ mainly by its reaction with superoxide to generate the stronger oxidant, peroxynitrite. ${ }^{18}$ Others suggested late HBO-induced vasodilation depends upon NO produced by both eNOS and nNOS. ${ }^{5}$ Besides, it was concurrent that nNOS was the main mediator of $\mathrm{NO}$ production responsible for $\mathrm{CBF}$ increase. ${ }^{6}$

In view of the multiple effect of $\mathrm{HBO}$ on cerebral blood vessel constriction and dilation, and seeing that the key role of $\mathrm{NO}$ produced by CMEC on cerebral blood vessel tension, we investigated the direct influence of $\mathrm{HBO}$ on CMEC, especially on the activity and expression of eNOS in it, by directly exposing CMEC to HBO. Although some studies reported $\mathrm{HBO}$ could increase the expression of eNOS in cultured endothelial cells, ${ }^{12}$ effect of $\mathrm{HBO}$ on CMEC and eNOS in it had not been reported before.

Our studies found the effects of 5 ATA HBO on eNOS in primarily cultured rat CMEC were as follow:

(1) When detected shortly after exposure, 30, 60 and $120 \mathrm{~min}$ exposure had no significant influence on NOS activity;

(2) When detected shortly and six h after exposure, 60 and 120 min exposure had no significant influences on eNOS protein and mRNA level;

(3) At $24 \mathrm{~h}$ after exposure, 30, 60 and $120 \mathrm{~min}$ exposures could increase the eNOS protein content by $39 \%, 60 \%$ and $40 \%$ respectively, mRNA content by $20-30 \%$. Although 10 and $20 \mathrm{~min}$ exposures had no effect on protein content, they could increase mRNA content by $15 \%$. The increased eNOS protein and mRNA contents at $24 \mathrm{~h}$ after exposure may reflect new protein synthesis for eNOS.

Based on our results, we thought $\mathrm{HBO}$ exposure could really increase the production of eNOS in cultured endothelial cells. At the same time, we thought that compared with the decrease of
CBF in vivo, which occurred in a relative short time after rat was exposed to HBO above 4 ATA, the responses of eNOS in CMEC in vitro were a little slow, even in consideration of the time needed for the balance of oxygen pressure in the culture medium and in ambient gas (5 ATA within $20 \mathrm{~min}$ ). Therefore, the effect of NO came from eNOS was limited for the vasodilation in the late period of $\mathrm{HBO}$ exposure before seizure. Some other studies had shown that the impacts of $\mathrm{HBO}$ exposure were potent on nNOS in rat brain, and $\mathrm{nNOS}$ was the main mediator of $\mathrm{NO}$ production associated with increase in $\mathrm{CBF}$ during $\mathrm{HBO}$ exposure. ${ }^{4,6,20}$ Moreover, eNOS may not be inhibited in the early period of exposure, although CBF decreased rapidly after the oxygen pressure was raised. As suggested by Demchenko et al. and Zhilyaev et al. this transient decrease was mainly resulted from inactivation of eNOS-dependent $\mathrm{NO}$ by $\bullet \mathrm{O}_{2}^{-}$, decreasing the basal vasorelaxing action of NO. ${ }^{17,18}$

Cerebral microvascular endothelial cell and neuron are different type cells. Our further investigations will focus on the difference of $\mathrm{HBO}$ modulation on NO production by eNOS in cerebral microvascular endothelial cell and by nNOS in neuron respectively.

\section{Materials and Methods}

Primary culture of rat CMEC. All experimental procedures were performed in adherence to the guidelines of Second Military Medical University on Animal Care and were approved by Second Military Medical University Animal Protocol Management and Review Committee.

Primary cultures of rat cerebral microvascular endothelial cells were prepared by modified methods described by Kis et al. and Abbott et al. ${ }^{21,22}$ Briefly, ten two-week-old SD rats were used for per culture. The cortexes were minced and incubated in collagenase type II. Then bovine serum albumin/dulbecco's minimum essential 


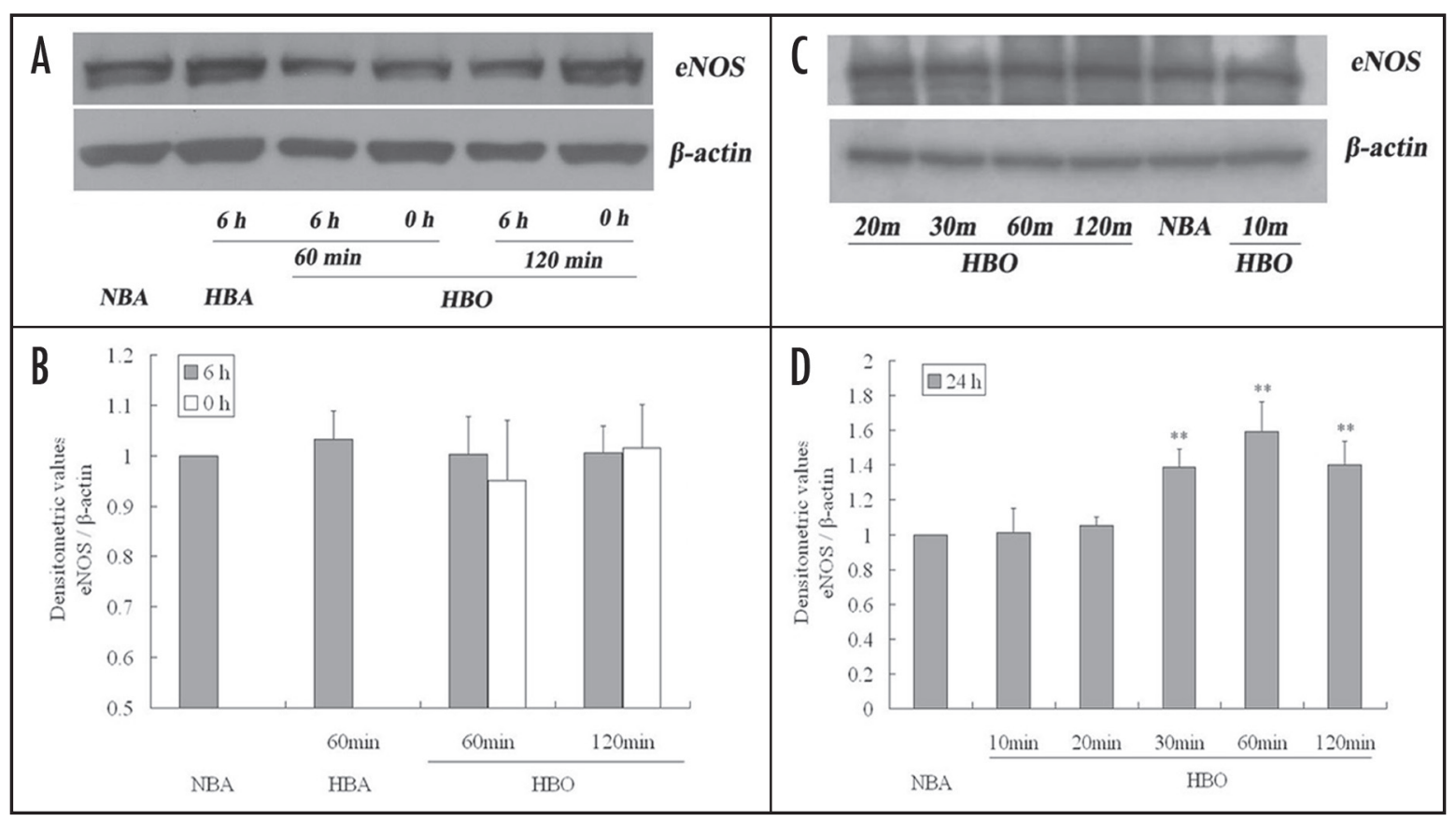

Figure 5. Immunoblots showing eNOS protein levels in primarily cultured CMEC after diverse exposure. (A and C) are representatives of 4 separate experiments. The bands in (A) show eNOS protein levels in CMEC at the moment immediately $(0 \mathrm{~h})$ or sequentially cultured in regular surroundings $(95 \%$ air- $5 \%$ $\mathrm{CO}_{2}$ ) for $6 \mathrm{~h}$ after different gas and period exposure. The bands in (C) show eNOS protein levels in CMEC sequentially cultured in regular surroundings for $24 \mathrm{~h}$ after different period of $\mathrm{HBO}$ exposure. ( $\mathrm{B}$ and $\mathrm{D})$ are summary of densitometric analyses of $(\mathrm{A}$ and $\mathrm{C})$ respectively. ${ }^{* *} \mathrm{p}<0.01$ vs. $\mathrm{NBA}, \mathrm{n}=4$.

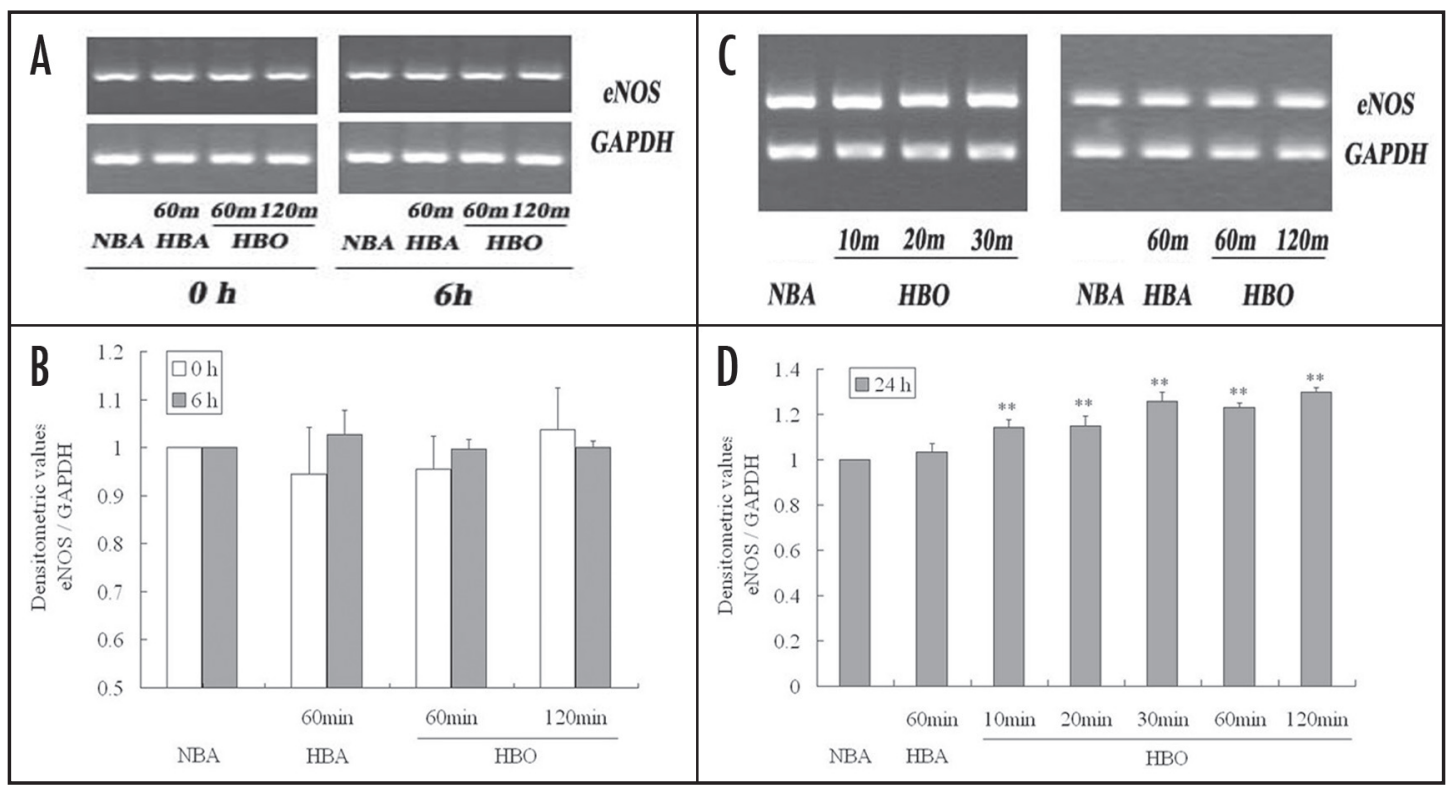

Figure 6. RT-PCR showing eNOS mRNA levels in primarily cultured CMEC after diverse exposure. (A and C) were representatives of 5 separate experiments. The bands in (A) show eNOS mRNA levels in CMEC at the moment immediately $(0 \mathrm{~h})$ or sequentially cultured in regular surroundings $\left(95 \%\right.$ air- $\left.5 \% \mathrm{CO}_{2}\right)$ for $6 \mathrm{~h}$ after different gas and period exposure. The bands in $(C)$ show eNOS protein levels in CMEC sequentially cultured in regular surroundings for $24 \mathrm{~h}$ after different gas and period exposure. (B and D): summary of densitometric analyses of $(A$ and $C)$ respectively. ${ }^{* *} p<0.01$ vs. NBA, $n=5$.

medium (DMEM) was added to the homogenate and centrifuged. The pellet was washed and further digested in collagenase/dispase. The cell suspension was layered on a $50 \%$ Percoll gradient, and then centrifuged. The band of the endothelial cell clusters was aspirated and washed. The cells were seeded onto collagen type IV and fibronectin coated plastic dishes (for Western blotting and RT-PCR) or glass coverslip for immunohistochemistry. From the second day basic fibroblast growth factor was added. The culture medium was changed every other day. The cells reached a confluent monolayer on $5-7^{\text {th }}$ day and consisted of more than $90 \%$ endothelial cells, verified by a spindle-shaped morphology and positive Factor VIIIrelated antigen. Such cells, after being starved with DMEM medium containing $1 \%$ fetal bovine serum (FBS) for $24 \mathrm{~h}$, were used for all experiments. 
HBO exposure. HBO exposure was performed in a small transparent chamber in which the temperature was controlled at $37 \pm$ $0.5^{\circ} \mathrm{C}$ and the humidity was controlled at the level of 100 percent. The gas mixture was composed of $99 \% \mathrm{O}_{2}$ and $1 \% \mathrm{CO}_{2}$ in order to maintain physiological $\mathrm{pH}$ at the experimental pressure. Cells were treated in opened $35 \mathrm{~mm}$ culture dishes or plates containing appropriate volume of DMEM medium with $1 \%$ FBS. After flushed with mixed gas for two minuites, the chamber pressure was reached to $500 \mathrm{kPa}$ (5 ATA) at rate of $100 \mathrm{kPa}$ per min and maintained for $10,20,30,60$ or 120 min according to respective experiments. After exposure, cells were treated immediately or sequentially cultured in regular normobaric air incubator (NBA, 95\% air- $5 \% \mathrm{CO}_{2}$ ) for 6 or $24 \mathrm{~h}$ for various assays. Cells of negative and normal control were respectively exposed to $\mathrm{HBA}\left(4 \% \mathrm{O}_{2}-95 \% \mathrm{~N}_{2}-1 \% \mathrm{CO}_{2}\right)$ at 500 $\mathrm{kPa}$ and NBA for equivalent period as $\mathrm{HBO}$ exposure.

Morphological observation and viability assay. Cell morphology was assessed by means of a phase-contrast optical microscope (Olympus) immediately and $24 \mathrm{~h}$ after $\mathrm{HBO}$ exposure.

Before viability assay, cells seeded on 96-well plates were exposed to HBA for $60 \mathrm{~min}$, or exposed to HBO for 60 or $120 \mathrm{~min}$. After exposure, cells were sequentially cultured in regular surroundings $\left(95 \%\right.$ air- $\left.5 \% \mathrm{CO}_{2}\right)$ for 6 or $24 \mathrm{~h}$. The viability was determined by the methyl thiazolyltetrazolium (MTT) assay. Briefly, MTT was added to the medium (final concentration $500 \mu \mathrm{g} / \mathrm{ml}$ ) and cells were incubated for $4 \mathrm{~h}$. After the crystals were completely dissolved in acidic isopropanol $(0.01 \mathrm{M} \mathrm{HCl}$ in $5 \%$ isopropanol and $10 \%$ sodium dodecyl sulphate (SDS)) at $37^{\circ} \mathrm{C}$, the optical density was determined at wavelength of $550 \mathrm{~nm}$ in ELISA reader (Bio-Tek Instruments). Results are expressed as mean \pm standard deviation (SD). Statistical significance was determined by the Student's t-test.

NOS catalytic activity. NOS activity was measured using Nitric Oxide Synthase Assay System (Beyotime, China), which is a simple and specific assay for the measurement of NOS activity in living cells under physiological conditions. This system use a cell-permeable fluorescent probe, 3-amino-4-aminomethyl-2',7'-difluorescein diacetate (DAF-FM DA), to react with NO produced by NOS to form a fluorescent triazolofluorescein. After exposure, cell monolayers were rinsed two times with $200 \mu \mathrm{l}$ Hank's Buffered Salt Solution (HBSS) each rinse to remove culture medium. Then $100 \mu \mathrm{l}$ reaction buffer and $100 \mu \mathrm{l}$ reaction mix containing the cofactor NADPH, arginine, and fluorescent probe were added to each well. Blank control was set by being only reaction buffer and reaction mix in well and cell-free. Incubate the plate at $37^{\circ} \mathrm{C}$, protected from light for two hours. Read the plate in spectrofluorometer with an excitation filter at $495 \mathrm{~nm}$ and an emission filter at $515 \mathrm{~nm}$. NOS activity was calculated by subtracting the value of blank control from the value of sample. The final representation of NOS activities in HBA and HBO exposed cells were presented as a percentage of that in NBA exposed cells.

Immunohistochemistry. Cells cultured on glass coverslip were fixed in $4 \%$ paraformaldehyde for $30 \mathrm{~min}$ immediately or six hours after $\mathrm{HBO}$ exposure. After pretreated in $1 \%$ hydrogen peroxide for 20 min, cells were incubated with rabbit polyclonal antibody against eNOS $\left(1: 100\right.$, Santa Cruz) for $24 \mathrm{~h}$ at $4^{\circ} \mathrm{C}$. Then cells were incubated with Biotin-conjugated goat anti-rabbit antibodies $(1: 200)$ for 3-4 h at room temperature. Diaminobenzidin (DAB) was used as the chromogen.
Western blotting analysis. Cells were washed and incubated in lysis buffer, then harvested and briefly sonicated. After centrifugation, the supernatant containing the equal amount of protein was resuspended in loading buffer. The buffer was subjected to SDS-polyacrylamide gel electrophoresis and then transferred to polyvinylidenedifluoride (PVDF) membrane. The membrane was blocked with nonfat dry milk in buffer. Blocked membranes were incubated with primary antibody (polycolonal antibody to eNOS, and monoclonal antibody to $\beta$-actin, Santa Cruz) overnight at $4^{\circ} \mathrm{C}$. Then membranes were incubated with 1:4,000 dilution secondary antibody (Santa Cruz) for one hour at room temperature. Proteins on the membranes were detected using an enhanced chemiluminescence detection kit (Amersham). For quantification, all blots were digitized with a scanner. Optical density of the bands was measured using Smartscape image analysis system (China). eNOS protein level was expressed as a ratio of eNOS's bend densitometric value divided by that of $\beta$-actin's respectively, and the final results were expressed as relative value referring to NBA eNOS protein level.

RT-PCR. Ice-cold lysis buffer was added to disrupt the cells. Total RNA isolation, reverse transcription, and semiquantitative competitive PCR were performed according to the instructions of RT-PCR kit (Qiagen). The sense (5'-TCC AGT AAC ACA GAC AGT GCA-3') and antisense (5'-CAG GAA GTA AGT GAG AGC-3') primers for eNOS amplified a 693-bp fragment of murine eNOS that was confirmed by DNA sequencing. Each PCR cycle consisted of denaturing at $94^{\circ} \mathrm{C}$ for 30 seconds (s), annealing at $58^{\circ} \mathrm{C}$ for 30 $\mathrm{s}$, and elongation at $72^{\circ} \mathrm{C}$ for $90 \mathrm{~s}$. The linear exponential phases for eNOS and glyceraldehydes phosphate dehydrogease (GAPDH) PCR were all 30 cycles. Equal amounts of corresponding NOS and GAPDH reverse transcription-PCR products were loaded on $1.5 \%$ agarose gels. Optical densities of ethidium-bromide stained DNA bands were quantitated using Smartscape image analysis system (China). eNOS mRNA level was expressed as a ratio of eNOS's bend densitometric value divided by that of GAPDH's respectively, and the final results were expressed as relative value referring to NBA eNOS mRNA level.

Statistical analysis. Data are presented as mean \pm SD. Differences between treatment and control groups were compared by unpaired two-tailed Student's t-test or by ANOVA. p values of $<0.05$ were considered statistically significant.

\section{Acknowledgements}

This work was supported by National Natural Science Foundation of China (No. 39900172). The authors thank Professor Maria A. Deli and Professor Xuan Bao for their great helps in cell culture.

\section{References}

1. Chavko M, Braisted JC, Outsa NJ, Harabin AL. Role of cerebral blood flow in seizures from hyperbaric oxygen exposure. Brain Res 1998; 791:75-82.

2. Demchenko IT, Boso AE, O'Neill TJ, Bennett PB, Piantadosi CA. Nitric oxide and cerebral blood flow responses to hyperbaric oxygen. J Appl Physiol 2000; 88:1381-9.

3. Sato T, Takeda Y, Hagioka S, Zhang S, Hirakawa M. Changes in nitric oxide production and cerebral blood flow before development of hyperbaric oxygen-induced seizures in rats. Brain Res 2001; 918:131-40.

4. Thom SR, Bhopale V, Fisher D, Manevich Y, Huang PL, Buerk DG. Stimulation of nitric oxide synthase in cerebral cortex due to elevated partial pressures of oxygen: An oxidative stress response. J Neurobiol 2002; 51:85-100.

5. Atochin DN, Demchenko IT, Astern J, Boso AE, Piantadosi CA, Huang PL. Contributions of endothelial and neuronal nitric oxide synthases to cerebrovascular responses to hyperoxia. J Cereb Blood Flow Metab 2003; 23:1219-26. 
6. Hagioka S, Takeda Y, Zhang S, Sato T, Morita K. Effects of 7-nitroindazole and N-nitrol-arginine methyl ester on changes in cerebral blood flow and nitric oxide production preceding development of hyperbaric oxygen-induced seizures in rats. Neuronsci Lett 2005; 382:206-10.

7. Honda S, Matsuo M. Shortening of the in vitro lifespan of human diploid fibroblasts exposed to hyperbaric oxygen. Exp Gerontol 1983; 18:339-45.

8. Padgaonkar V, Giblin FJ, Reddan JR, Dziedzic DC. Hyperbaric oxygen inhibits the growth of cultured rabbit lens epithelial cells without affecting glutathione level. Exp Eye Res 1993; 56:443-52.

9. Tompach PC, Lew D, Stoll JL. Cell response to hyperbaric oxygen treatment. Int J Oral Maxillofac Surg 1997; 26:82-6.

10. Rothfuss A, Stahl W, Radermacher P, Speit G. Evaluation of mutagenic effects of hyperbaric oxygen (HBO) in vitro. Environ Mol Mutagen 1999; 34:291-6.

11. Huang KL, Wu JN, Lin HC, Mao SP, Kang B, Wan FJ. Prolonged exposure to hyperbaric oxygen induces neuronal damage in primary rat cortical cultures. Neurosci Lett 2000; 293:159-62.

12. Buras JA, Stahl GL, Svoboda KK, Reenstra WR. Hyperbaric oxygen downregulates ICAM1 expression induced by hypoxia and hypoglycemia: The role of NOS. Am J Physiol Cell Physiol 2000; 278:292-302.

13. Krizanac-Bengez L, Kapural M, Parkinson F, Cucullo L, Hossain M, Mayberg MR, et al. Effects of transient loss of shear stress on blood-brain barrier endothelium: Role of nitric oxide and IL-6. Brain Res 2003; 977:239-46.

14. Elayan IM, Axley MJ, Prasad PV, Ahlers ST, Auker CR. Effect of hyperbaric oxygen treatment on nitric oxide and oxygen free radicals in rat brain. J Neurophysiol 2000; 83:2022-9.

15. Demchenko IT, Boso AE, Whorton AR, Piantadosi CA. Nitric oxide production is enhanced in rat brain before oxygen-induced convulsions. Brain Res 2001; 917:253-61.

16. Demchenko IT, Oury TD, Crapo JD, Piantadosi CA. Regulation of the brain's vascular responses to oxygen. Circ Res 2002; 91:1031-7.

17. Demchenko IT, Atochin DN, Boso AE, Astern J, Huang PL, Piantadosi CA. Oxygen seizure latency and peroxynitrite formation in mice lacking neuronal or endothelial nitric oxide synthases. Neurosci Lett 2003; 344:53-6.

18. Zhilyaev SY, Moskvin AN, Platonova TF, Gutsaeva DR, Churilina IV, Demchenko IT. Hyperoxic vasoconstriction in the brain is mediated by inactivation of nitric oxide by superoxide anions. Neurosci Behav Physiol 2003; 33:783-7.

19. Oury TD, Ho YS, Piantadosi CA, Crapo JD. Extracellular superoxide dismutase, nitric oxide and central nervous system $\mathrm{O}_{2}$ toxicity. Proc Natl Acad Sci USA 1992; 89:9715-9.

20. Chavko M, Xing GQ, Keyser DO. Increased sensitivity to seizures in repeated exposures to hyperbaric oxygen: Role of NOS activation. Brain Res 2001; 900:227-33.

21. Kis B, Deli MA, Kobayashi H, Abraham CS, Yanagita T, Kaiya H, et al. Adrenomedullin regulates blood-brain barrier functions in vitro. Neuroreport 1999; 12:4139-42.

22. Abbott NJ, Hughes CC, Revest PA, Greenwood J. Development and characterisation of a rat brain capillary endothelial culture: Towards an in vitro blood-brain barrier. J Cell Sci 1992; 103:23-37. 


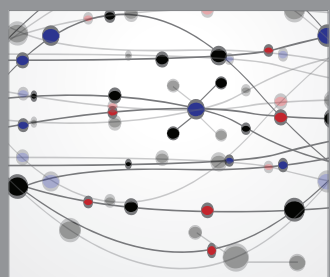

The Scientific World Journal
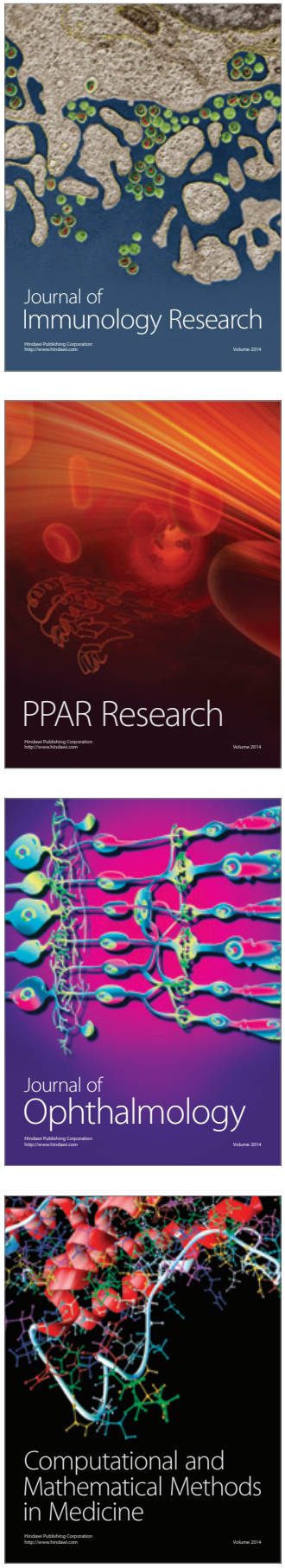

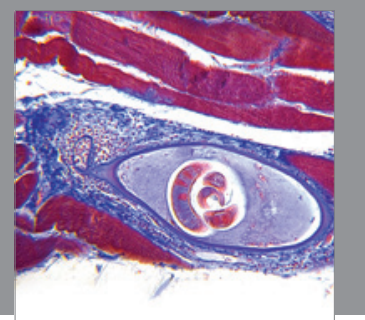

Gastroenterology

Research and Practice
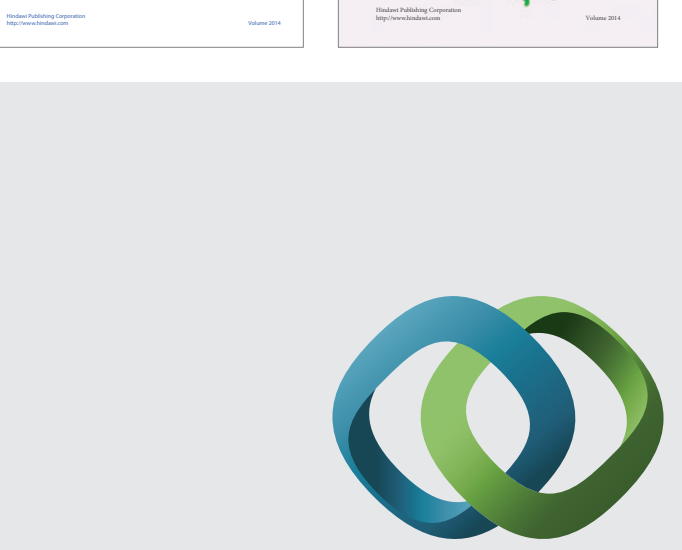

\section{Hindawi}

Submit your manuscripts at

http://www.hindawi.com
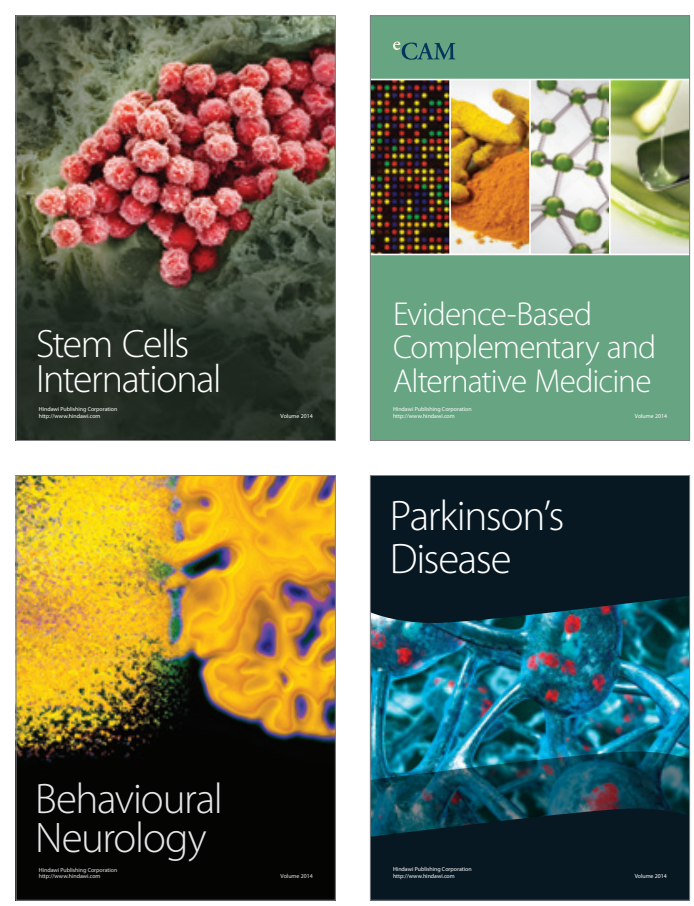

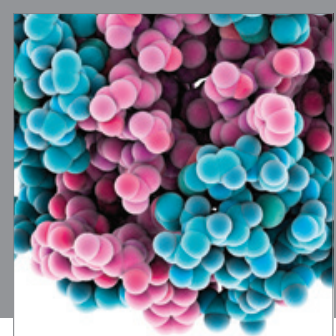

Journal of
Diabetes Research

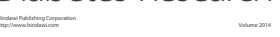

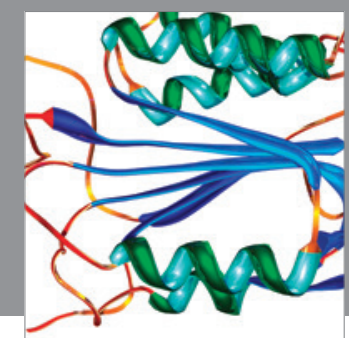

Disease Markers
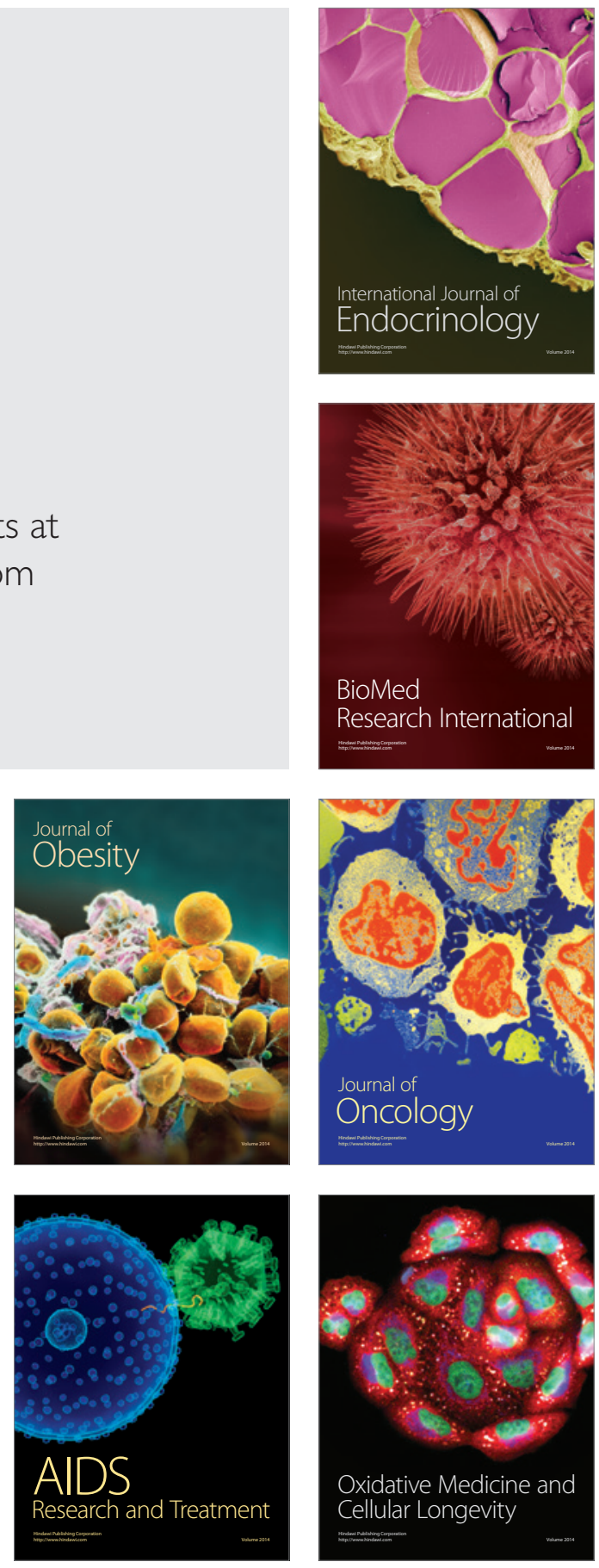